\title{
Stuðningsmeðferð í tannréttingum
}

GÍSLI EINAR ÁRNASON, CAND. ODONT.

SÉRFRAEIINGUR Í TANNRÉTTINGUM, AKUREYRI

NETFANG: GISLI@TANNRETTING.IS TANNLAEKNABLAĐIĐ 2021; 39(2): 32-36

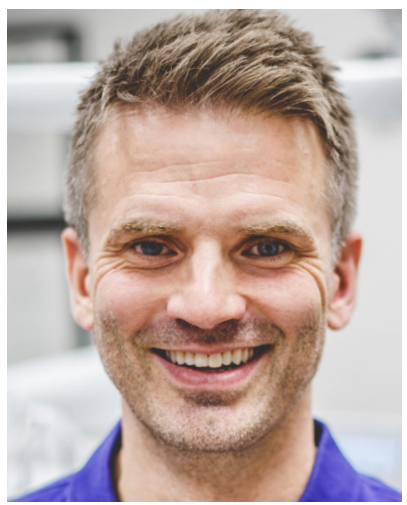

Doi: 10.33112/tann.39.2.3

\section{ÁGRIP}

Stuðningur eftir tannréttingameðferð er mikilvægur páttur meðferðar til að koma í veg fyrir bakslag og óhagstæðar breytingar á stöðu tanna og biti. Bakslag eftir tannréttingar stafar af togi frá tannhaldspráđum sem vilja færa tennur aftur í upphaflega stöðu, en getur einnig stafað af óeðlilegum bitkröftum á tennur ef bitafstaða er ekki rétt. Vöxtur kjálka og aldursbreytingar mjúkvefja munnholsins geta einnig haft áhrif á stöðugleika tannréttingameðferðar. Pað er pví mikilvægt að tannréttingasérfræðingur, sjúklingur og viðkomandi almennur tannlæknir skilji tilgang og ástæðu stuðningsmeðferðar.

Lykilorð: stuðningsmeðferð, tannréttingar, bakslag, stoðbogi

\section{Inngangur}

Stuðningsmeðferð eftir tannréttingar er mikilvægur páttur í pví að stuðla að langtíma árangri meðferðar.

Lengi vel töldu tannlæknar að eina leiðin að stöðugri tannréttingu væri fullkomlega rétt bit par sem tennur væru staðsettar rétt með tilliti til undirliggjandi beins. Starfshæfni tyggingafæra í heild hefur einnig verið nefnd sem ráðandi páttur í stöðugri tannréttingu (1). Nú orðið er ljóst að stuðningsmeðferð eftir tannréttingar er flókið ferli par sem taka parf tillit til fjölda pátta.

Mismunandi bitskekkjupættir hafa mis mikil áhrif á bakslag eftir tannréttingar, en hversu mikil tilhneigingin er til að tennur gangi tilbaka fer eftir peirri meðferð sem var veitt. Pví er augljóst að undirbúningur að stöðugri tannréttinga útkomu hefst við gerð meðferðarplans, en ekki eftir að virkri tannréttingameðferð lýkur!

\section{Breytingar eftir tannréttingameðferð}

Tennur hreyfast og bit próast alla ævi. Stærstu og hröðustu breytingar á tannsettinu eru á tannskipta aldri pegar barnatennur falla og fullorðinstennur koma í munn. Á sama tíma er einnig mikill kjálkavöxtur í gangi sem hefur áhrif á stöðu tanna og bit.

Eðlilegur líkamlegur vöxtur og próun hefur áhrif á stöðu tanna eftir tannréttingameðferð. Almennt er hægt að búast við vægri breikkun á tannbogum fram undir pað að fullorðins augntennur koma í munn, en eftir pað mjókka tannbogar á milli augntanna. Pað má pví segja að breidd tannboga á milli jaxla er stöðug frá unglingsaldri, en prengsli aukast á framtannasvæði (2).

Sýnt hefur verið fram á i íslenskum rannsóknum að af 250 fulltenntum einstaklingum sem aldrei fóru í tannréttingar voru 8,8\% með prengsli á neðra framtannasvæði um 12 
ára aldur, en í sama hópi 26 árum seinna voru pað 15,6\%. Á sama tíma hjá sama hóp minnkaði líka gleiðstaða efri framtanna úr pví að vera á meðal 11,6\% einstaklinga í að vera á meðal 2,8\% í sama hóp (3). Pví má segja að tennur sem aldrei hafa verið meðhöndlaðar með tannréttingu breyta einnig um stöðu með tímanum og framtannaprengsli aukast frá unglingsaldri. peir pættir sem taldir eru stuðla að auknum prengslum á framtannasvæði eru m.a. stytting á tannbogum með hækkandi aldri, og að með framvexti neðri kjálka færast neðri góms framtennur aftar (e. lingualt) (3).

prátt fyrir að eðlilegar aldurstengdar breytingar eru einn páttur í bakslagi eftir tannréttingar er vert að ræða frekar pá pætti sem tannréttingameðferðin sjálf hefur áhrif á.

Tannhaldspræðir - tannhaldspræðir sem umlykja tannháls tanna og peir præðir sem fara á milli aðlægra tanna eru taldir hafa mest áhrif á bakslag. Við tannréttingu verður tog á pessa præði sem leitast við að færa viðkomandi tönn aftur í sína upphaflegu stöðu. Á petta sérstaklega við um tennur sem hefur verið snúið í tannréttingameðferð. Talið er að pað taki um 8 mánuði fyrir pessa præði að endurraða sér í hlutlausa stöðu (4).

Bitið - lengi hefur verið talað um að hlutlaust bit með mörgum jöfnum bitsnertingum sé besta leiðin til stöðugrar tannréttingar. Réttur framtannahalli og bitsnertingar í samanbiti kemur í veg fyrir að bit dýpki á ný eftir meðferð og rétt jaxlabit hefur áhrif á stöðugleika bæði breiddar tannboga og classa II/III leiðréttingar $(2,5)$.

Tannréttingameðferð - ýmsar hreyfingar og/eða leiðréttingar sem framkvæmdar eru i tannréttingameðferð eru óstöðugari en aðrar. Óstöðugar hreyfingar eru t.d.:

- Breytingar á tannbogaformi neðri tannboga (6)

- Aukin breidd á milli augntanna neðri góms - petta er sú hreyfing sem er viðkvæmust að gangi tilbaka (2)

- Snúningar á framtönnum

- Aukin framtannahalli neðri góms framtanna (7) og par af leiðandi aukið framstæði með tilliti til vara

Ákveðnar vísbendingar eru um að við glerungsslípun (e. interproximal reduction) á milli framtanna neðri góms í tannréttingameðferð verði staða neðri framtanna stöðugri (8).

Langtíma rannsóknir benda til að eftir tannréttingameðferð sé aukin hætta á að prengsli taki sig upp aftur á neðra framtannasvæði ef viðkomandi gekkst undir tannréttingameðferð án úrdráttar. Ef tannréttingameðferð fór fram með úrdrætti eru minni líkur á bakslagi í stöðu neðri góms framtanna (3).
Umhverfispættir/vöðvar - tennur eru staðsettar innan tannboga par sem jafnir kraftar verka á pær annars vegar tungumegin (prýstingur frá tungu) og hins vegar vara- og kinnamegin. Ef pessu jafnvægi er raskað með tannréttingu (t.d. breyting á tannbogaformi, stöðu og halla á framtönnum, o.fl.) má búast við aukinni tilhneigingu til bakslags (7).

Endajaxlar - neðri góms endajaxlar auka ekki líkur á að neðri framtennur skekkist aftur eftir tannréttingameðferð. Ekki er mælt með úrdrætti á neðri né efri góms endajöxlum til að koma í veg fyrir bakslag í stöðu framtanna eftir tannréttingameðferð (1).

Eftirlit með álímdum stoðbogum:

- Fylgjast með stoðbogum - er vír brotinn eða aflagaður?

- Hreinsa umhverfi stoðboga - hvetja til og kenna góða tannhirðu við stoðboga

- Gera við límingar - hreinsa burt gamalt plastblendi og setja nýtt ef pörf er á

\section{Tegundir stuðningsmeðferðar}

\section{Álímdur stoðbogi}

Stoðbogi er formaður í munni eða á tannsmíðaverkstæði og límdur aftan á framtennur við lok tannréttingameðferðar. Í efri gómi er stoðbogi gjarnan límdur á fjórar framtennur (Mynd 1). Neðri góms stoðbogi nær oftast aftur á augntennur og er ýmist límdur eingöngu á augntennur og styður pá við framtennur og viðheldur breidd á milli augntanna (e. intercanine distance) (Mynd 2), eða að léttari og sveigjanlegri stoðbogi er límdur á augntennur og allar framtennur.

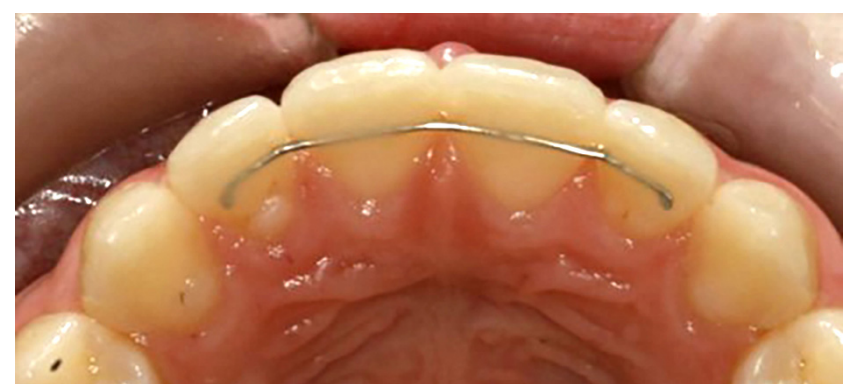

Mynd 1. Stoðbogi i efri gómi. 


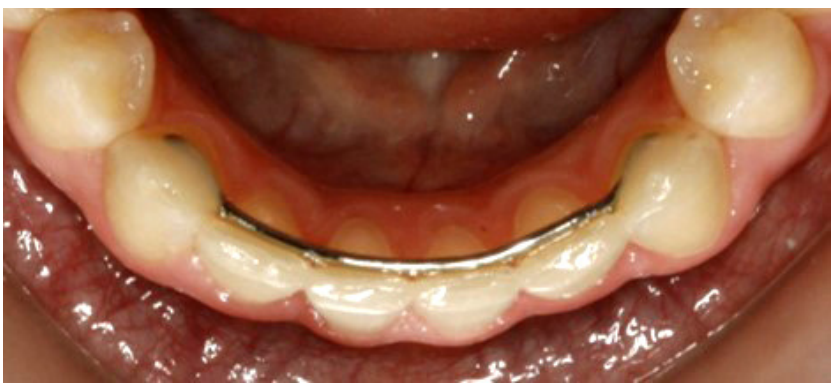

Mynd 2. Stoðbogi i neðri gómi.

Kostir álímdra stoðboga er að ekki er krafist meðferðarheldni af hálfu sjúklings, stoðboginn er alltaf til staðar og sem slíkur pá styður hann við tennur. Gallar slíkra stoðboga er að límingar geta bilað og veitir hann pá falskt öryggi. Einnig getur tannsýkla og tannsteinn sest á og við stoðbogann. Pví er mikilvægt að tannlæknir leiðbeini sérstaklega um tannhirðu við stoðboga og fjarlægi reglulega tannstein sem kann að myndast.

Rannsóknir sýna að stoðbogi í neðri gómi sem límdur er eingöngu á augntennur (sjá mynd 2) safnar minni tannsýklu og veldur síður tannhaldsbólgu, en stoðbogi sem límdur er á allar framtennur (9). Önnur rannsókn sem fylgt hefur álímdum stoðbogum i 8,5 ár sýnir að prátt fyrir að tannsýkla geti sest á eða við stoðboga pá hefur stoðboginn ekki skaðleg áhrif á tannhald eða glerung (10).

\section{Gómplata}

Hawley eða Jensen tegundir af gómplötum (Mynd 3) styðja við efri tannboga og hafa virkan eða óvirkan varaboga (e. labialbow). Kostur slíkra gómplatna er að pær styðja við tannbogaform ef pví hefur verið breytt í tannréttingameðferðinni, og halda auk pess úrdráttarbilum lokuðum. Varaboginn styður auk pess við stöðu augntanna efri góms. Par sem bitfletir tanna eru ekki huldir pá gefur gómplata tönnum einnig færi á að setjast í skorður m.t.t. bits (e. posterior occlusal settling). Gómplata er oft notuð fyrstu mánuði eða ár eftir að virkri tannréttingameðferð lýkur, en sjaldan til frambúðar.

\section{Skinna}

Glær hitaformuð skinna (Mynd 4) sem fellur vel utan um tennur er, eins og gómplatan, laust tæki til stuðnings eftir tannréttingu. Skinnan sést minna en gómplatan. Líklega má telja að skinnur styðji ekki jafn vel við breidd og form tannboga eins og gómplata. Skinnur hylja bitfleti jaxla og séu pær notaðar dag og nótt má ætla að pær styðji betur við lóðréttar breytingar tannréttingameðferðar - hjá einstaklingum sem hafa tilhneigingu til opins bits.

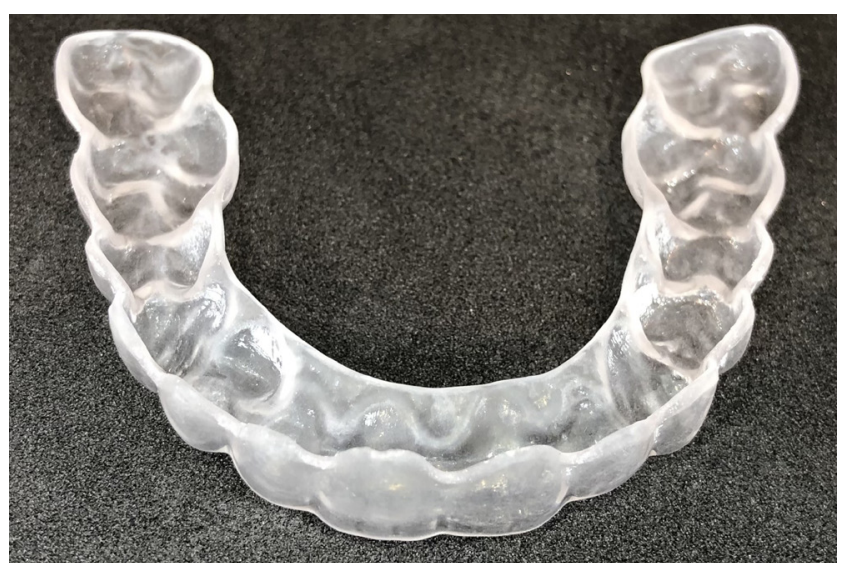

Mynd 4. Skinna til stuðnings eftir tannréttingu.

Mikilvægt er að fræða sjúkling með skinnu um að hana skal fjarlægja pegar matast er og drukkið, sem og pegar tennur eru hirtar (Mynd 5).

Gómplötur og skinnur eru oftast notaðar samfara álímdum stoðbogum, en sjaldnast einar og sér.

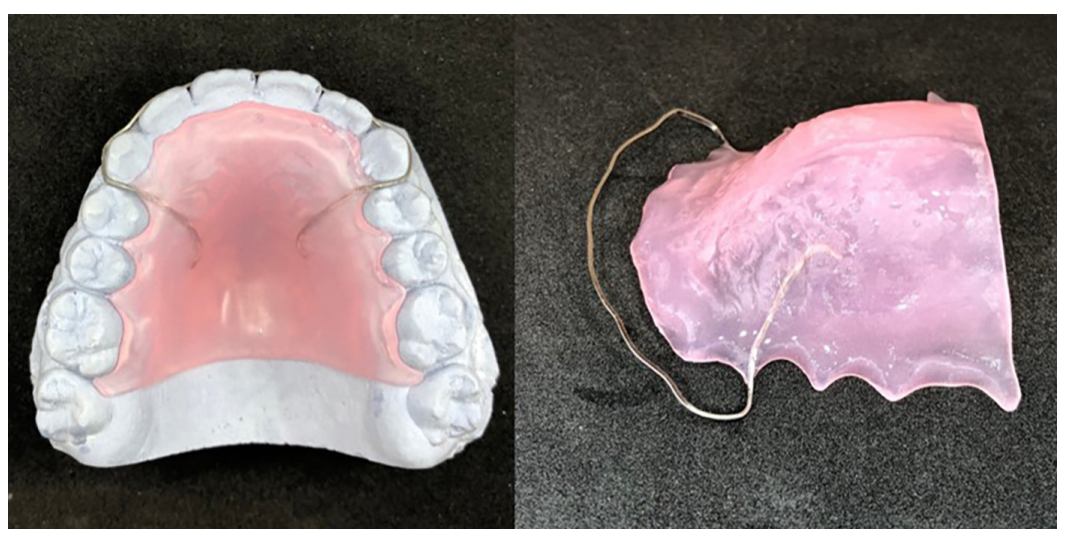

Mynd 3. Jensen gómplata. 


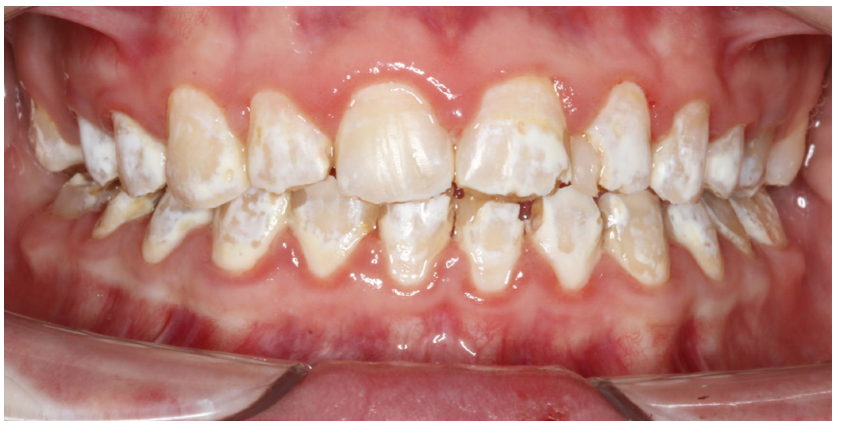

Mynd 5. Miklar og dreifðar úrkalkanir par sem skinna var ekki fjarlægð til að hirða tennur.

\section{Tími}

Hve lengi skal styðja við tennur eftir tannréttingameðferð? Við pví er einfalt svar - pví lengur pví betra!

prátt fyrir að tannhaldspræđir við tannhálsa hafi endurraðað sér eftir 8 mánuði ber að taka tillit til peirrar tannréttingameðferðar sem var framkvæmd, stöðu tanna fyrir tannréttingameðferð, stöðu tanna m.t.t. umhverfispátta, bits, vaxtar o.fl.

Ef tannhirða er góð og óskir sjúklings eru að staða neðri góms framtanna haldi sér sem lengst er skynsamlegt að hafa álímdan stoðboga sem lengst! Petta ber tannréttingasérfræðingi og tannlækni að fræða viðkomandi sjúkling um.

Mælt er með langtíma stuðningsmeðferð í eftirfarandi tilfellum: (11)

- Umtalsverð prengsli og snúningar á framtannasvæði neðri góms

- Framtannahalli neðri góms framtanna töluvert aukin við tannréttingameðferð

- Lág beinhæð eða stuttar rætur

- Gleiðstaða tanna í upphafi

- Ófullnægjandi tannrétting - par sem bit styður ekki við stöðu tanna

\section{Umræður}

Tæpt hefur verið á nokkrum páttum er varðar stöðugleika eftir tannréttingameðferð. Fleiri pætti mætti tína til en verður ekki gert.

Pó að tannréttingameðferð sé aldrei fullkomlega stöðug pá er pað í verkahring tannréttingasérfræðings að plana, útfæra og framkvæma pá meðferð sem felur í sér sem allra mesta stöðugleika pegar tekið er tillit til allra ofangreindra pátta. pað hefst með góðu meðferðarplani og rétt útfærðri meðferð.

Stuðningsmeðferð eftir tannréttingar er ófrávíkjanlegur páttur meðferðar ef hún á að vera stöðug. Aðstæður eiga að ráđa pví hvaða stuðningsmeðferð er ákjósanleg í hverju tilfelli og sjúklingur parf að vera meðvitaður um tannhirðu við stoðtæki, tímalengd og áhrif pess ef stuðningsmeðferð er hætt.

\section{Heimildir}

1. Littlewood et al. Retention and relapse in clinical practice. Aust Dent J 2017; 62:5157.

2. Blake et al. Retention and Stability: A review of the literature. Am J Orthod Dentofacial Orthop 1998; 114:299-306.

3. Jonsson and Magnusson. Crowding and spacing in dental arches: Long-term development in treated and untreated subjects. Am J Orthod Dentofacial Orthop 2010; 138(4):384. e1-384.e7.

4. Reitan K. Clinical and histologic observations on tooth movement during and after orthodontic treatment. Am J Orthod 1967; 53:721-745.

5. Reitan K. Tissue rearrangement during retention of orthodontically rotated teeth. Angle Orthod 1958; 29:105-113.

6. Carter GA et al. Longitudinal dental arch changes in adults. Am J Orthod Dentofacial Orthop 1998; 114:88-99.

7. Houston WJB et al. Long-term stability of the lower labial segment relative to the A-Pg line. Europ J Orthod 1990; 12:302-10.

8. Boese LR. Fiberotomy and reproximation without lower retention -9 years in retrospect: Parts 1 and 2. Angle Orthod1980; 50:88-97, 169-178.

9. Rody Jr. et al. Effects of different orthodontic retention protocols on the periodontal health of mandibular incisors. Orthod Craniofac Res 2016; 19:198-208.

10. Sadowsky $C$ et al. Long-term stability after orthodontic treatment: nonextraction with prolonged retention. Am J Orthod Dentofacial Orthop 1994; 106:243-249.

11. Johnston CD et al. Retention in orthodontics. Br Dent J 2015; 218:119-122. 


\section{English Summary}

\section{Orthodontic Retention}

\section{GISLI EINAR ARNASON, CAND. ODONT. ORTHODONTIC SPECIALIST, PRIVATE PRACTICE, AKUREYRI}

EMAIL: gisli@tannretting.is ICELANDIC DENT J 2021; 39(2): 32-36 doi: 10.33112/tann.39.2.3

Retaining favorable tooth position and bite relation after orthodontic treatment is an important part of the orthodontic treatment. This is to avoid tooth relapse and unwanted bite changes. Orthodontic relapse is caused by a constant pull from interdental fibers - pulling the respective tooth to its original position. It may also be caused by unfavorable bite forces if sufficient bite correction was not achieved. Growth and age related changes in soft tissue can also add to the instability of the orthodontic treatment. It is therfore important that the orthodontist, the patient and the patients' general dentist have knowledge and understanding of the importance of the retention method applied.

Keywords: orthodontic treatment, relapse, retainer, retention

Correspondence: Gisli Einar Arnason, email: gisli@tannretting.is 